\title{
Media Use and Relationships of Children with Their Peers During the Transition from Preschool to Primary School - In Cases of TV, Mobile Phone and Computer
}

\author{
Yanfang Zhou \\ Atsushi Nanakida \\ Yuan Long \\ Graduate School of Education \\ Hiroshima University, Japan \\ Art Department \\ Guangdong Polytechnic College, China
}

\begin{abstract}
This study examined whether children's media use reflect on their peer relationships during the transition to primary school.Participants include representative samples of 312 families with 4-6 years old children(312 children of both sexes)in China.The data were derived from interview and questionnaire.Qualitative analysis,correlation analysis, exploratory factor analysis, AVONA and "T"test were adopted in this study. Results revealed a bidirectional relationship between media use and peer relationship.There are 3 main ways in which media are used as a part of daily life for young children:(1)Using media as a tool when together with peers.(2)Using media as a topic in play and talk;(3)Using media as means of self-development(social identity).Both gender and age in media use were analyzed and showed significant relations.The amount of time in children's media use has a significant impact on social understanding and social participation, and ultimately affects peer acceptance.
\end{abstract}

Keywords: Media use peer relationship transition to primary school

\section{Introduction}

Early school transitions is a milestone in children's integral development and play an important role in later school success.(Love, J. M., Logue, M. E., Trudeau, J. V., \& Thayer, K.1992;Alexander \& Entwisle, 1988; Ladd, Buhs, \& Seid, 2000;Rous, B., Hallam, R., Harbin, G., McCormick, K, \& Jung, L. (2007) A transition is a movement from one environment or setting to another. As for the children's transition to primary school refers to children on the stage in which they go through various challenges to develop overall capabilities and obtain social

development.(Fabian,2007; Ines Blažević,2016).There has been evidence that children who experienced favorable and smooth transition are more likely to have higher levels of social capacities and competence.(Shepard \& Smith,1989; Peters, 2010; ${ }^{1}$ Sayers, West, Lorains, Laidlaw, Moore and Robinson, 2012) Consistent researches have evidenced that children's transiton to primary school is affected by different environments or settings (e.g. home, daycare center, community, school) (Pianta,2000;Rimm-Kaufman, $\left.{ }^{2}, 2000,2005\right)^{3}$; Dockett, S., Perry,B,2007 ${ }^{4}$ )

Children are expected to obtain a higher performance both socially and academically for subsequent school years. Therefore, there is a need for research on various surroundings and environments that contribute to children`s social and emotional adjustment to primary school.

Transitions tend to be theorized through a ecological system approach. According to Bronfenbrenner, a child's

\footnotetext{
${ }^{1}$ Peters, S. (2010). Literature Review: Transition from Early Childhood Education to School - Report to the Ministry of Education New Zealand. Retrieved November 2013, from http://lnxweb1.manukau.ac.nz/_data/assets/pdf_file/0008/85841/956_ECELitReview.pdf

${ }^{2}$ Rimm-Kaufman, S. E.,\&Pianta, R. C. (2000). An ecological perspective on the transition to kindergarten: A theoretical framework to guide empirical research. Journal of Applied Developmental Psychology, 21, 491-511.

Rimm-Kaufman, S. E.,\&Pianta, R. C. (2005). Family-school communication in preschool and kindergarten in the context of a relationship-enhancing intervention. Early Education and Development, 16, 287-316.

${ }^{3}$ Pianta, R. C., Cox, M. J., Taylor, L., \& Early, D. (1999). Kindergarten teachers' practices related to the transition to school: Results of a national survey. Elementary School Journal, 100(1), 71-86.

${ }^{4}$ Dockett, S., \& Perry, B. (2007). Children's transition to school: Changing expectations. In A-W. Dunlop, \& H. Fabian (Eds.), Informing transitions in the early years: research policy and practice (1 ed., pp. 92-104). [7] London: Open University Press.
} 
development is shaped by the varied systems of the child's environment and also by the interrelationships among the systems. The relationship between the child and the environment as he saw it is reciprocal; the environment influences the child and the child influences the environmen $t$ (Bronfenbrenner 1979, 1992 ${ }^{5}$; Bronfenbrenner and Morris, 2006). ${ }^{6} \mathrm{a}$ microsystem, mesosystem, exosystem and macrosystem are defined in the ecological system theory and the disciples of interaction and mutual influence between individuals and environments are outlined.(Figure1,The ecological system)

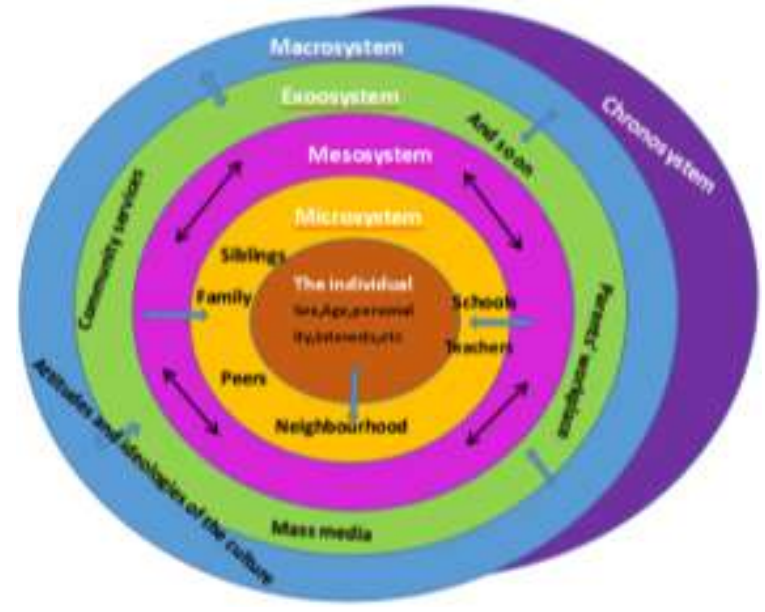

Among this system, along with digitized time arrival, with the popularization of computers, televisions, mobile phones, tablets, game consoles and other media, children's lives have undergone profound changes. Accessing to the various media has become a part of children's every day life.(Figure 2)

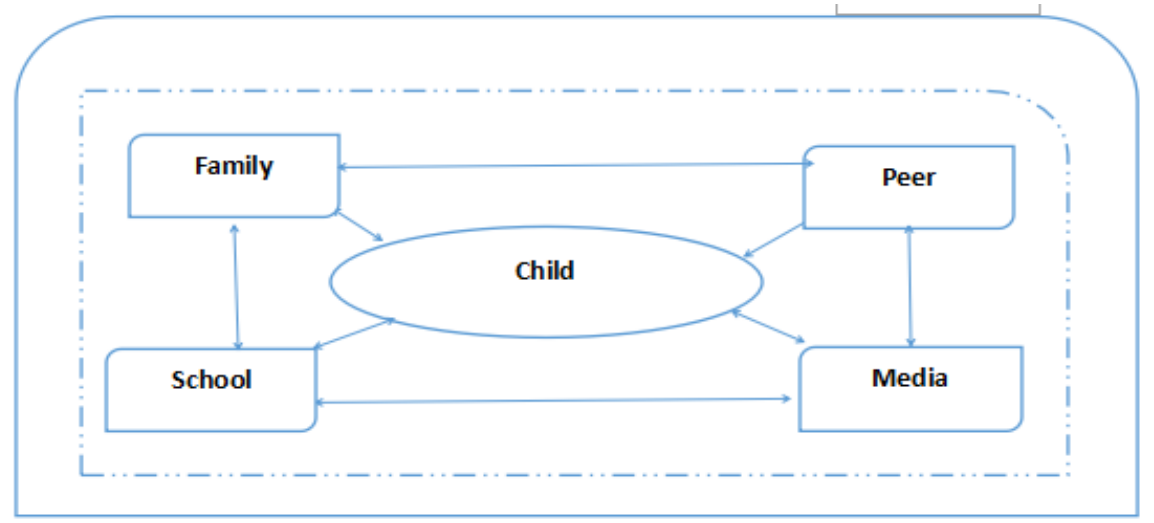

(Figure 2)

Forming the first friendships in this period is extremely an important issue for the children(Klarin,2002,Berk,2008,). The peer relation plays an important role in children's social and emotional develpoment and provides various chances for children to learn how to conteract with others, to obtain wide range of congnition and development.(Kupersmidt \& Coie, 1990;Rubin, K. H., Dwyer, K. M., Booth, C. L., Kim, A. H., Burgess, K. B., \& Rose-Krasnor, L.(2004)Changes are significant in the early years for children, including their psychological states, individual needs, emotions and social behaviour, thus influenced easily by the circumstances or contexts.(Colker,Heroman,2001)Mutual interests and participation into topics and activities are preferable ways to build up their friendships in peer groups and gain peer acceptance or identity(Ines Blažević,2016)

The past research reviewed so far shows that quite a substantical number of studies have been devoted to examining the

\footnotetext{
${ }^{5}$ Bronfenbrenner, U. (1979). The Ecology of Human Development: Experiments by Nature and Design. Cambridge, MA: Harvard University Press. Bronfenbrenner, U. (1992). Ecology of the Family as a Context for Human Development: Research Perspectives. Developmental Psychology, 22, 6, 723-742. Bronfenbrenner, U., and Morris, P. (2006). The Bioecological Model of Human Development. In Lerner, R.M. (Ed.) Theoretical Models of Human Development (Volume 1 of Handbook of Child Psychology) (6th Edition). pp 793-828. Hoboken, NJ: Wiley.

${ }^{6}$ Mashburn, A., and Pianta, R. (2006). Social Relationships and School Readiness. Early Education and Development, 17, 151-176. 
relationships of parents, teachers and peers among children in the transition period(Wai,2012; Saraswatee Rajiah,2017;Annarilla\&Gintautas,2011) However, to the best of the author's knowledge, empirical studies remain indispensable for a further exploration on the relationships between the individuals and physical environment. As figure 3 shows below,

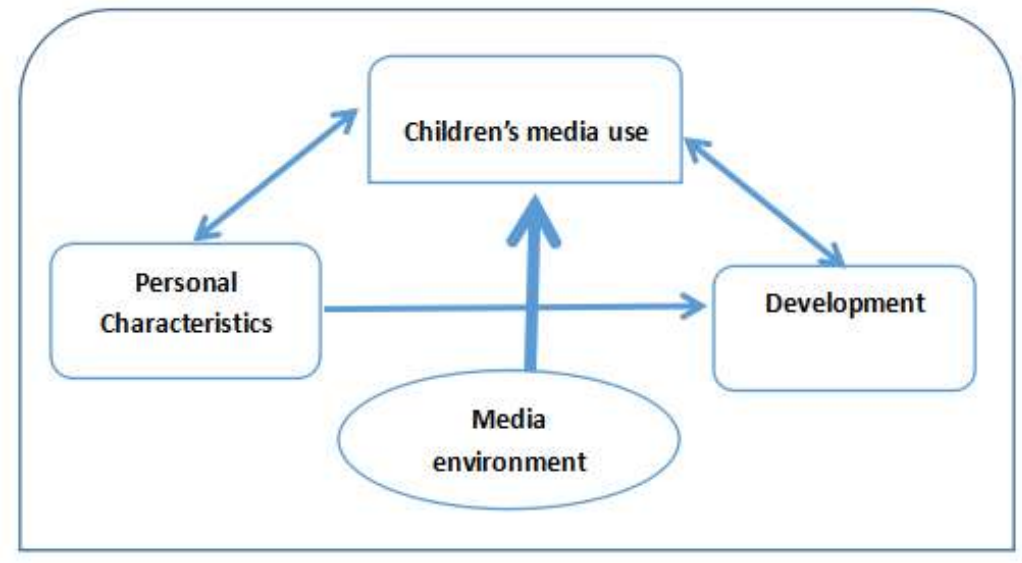

(Figure 3)

In accordance with Daniel Suess and Annikka Suoninen(1998)'s view, In the process of using the media, children not only have the need for social interaction, but also the need for self-identity. This article focuses on the role of peer relationship in the use of different media genres and different contents among children. what's more, the influence of media use on peer relations, similarities and differences in gender and grade when children use media in the transition to primary school are also given a concern here.

\section{Definition}

What is media?

Media are the communication tools or channels used to store and disseminate information or data. Children's media use refers to the behavior of children to meet their needs through the use of certain mainstream media(TV, Mobile phone, Tablet, PC) under the influence of certain social factors. This behavior can be indicated by the frequency, the amount of time, content, and genre of media in which the child is exposed to.

\section{Theoretical framework}

1.Bronfenbrenner's ecological theory (1979) emphasises the importance of the environment for children's social development (Vasta,1998; Bronfenbrenner\&Ceci,1994).Transitions tend to be theorised through a ecological system approach. According to Bronfenbrenner, a child's development is shaped by the varied systems of the child's environment and also by the interrelationships among the systems. The relationship between the child and the environment as he saw it is reciprocal; the environment influences the child and the child influences the environment. In the context of this theory, it is important to influence on children's social development with potential social interactions by social environment, but without neglecting his personal development.

\section{Erikson's theory of psychosocial development}

Erikson points out that ego goes through 8 stages of development, At each stage an individual needs to overcome some "crisis" from which an attitude is developed towards oneself and other people. At different age the child tries to overcome all tasks that are given to him/her, and if in the previous stage the initiative has developed then it will greatly help him/her in this developmental age. From Erikson's pesperctive of psychosocial development, it is very important to develop children's "ego" or "identity" at proper situations.

\section{Methodology}

1.Questionnaire data were derived from 312 families with children aged 4- 6 in different cities in eastern and central China during January to the end of March 2019.

2.Semi-structured Interview.

\section{Measures and procedures}

1.General media use questionnaire for children and family member. they are including the items of TV, mobile phone, tablet and computer.

2.Preschool and Kindergarten Behavior Scales(Cronbach's Alpha 
$=0.939)$

The breakdown of the study participants is as follows:

(1) $15 \mathrm{~K} 3$ children

(2) 15 P1children

(3) 162 parents of $\mathrm{K} 3$ children

(4) 150parents of P1 children

Table 1 The distribution of subjects(Questionnaire)

\section{Gender * Grade Crosstabulation}

The distribution of subjects

\begin{tabular}{|c|c|c|c|c|c|}
\hline & \multicolumn{2}{|l|}{ Grade } & \multirow[b]{2}{*}{ Total } & \multirow[b]{2}{*}{ Percent } \\
\hline & & $\begin{array}{l}\text { Kindergarte } \\
\text { n }\end{array}$ & Primary school & & \\
\hline \multirow{4}{*}{$\begin{array}{l}\text { Gender } \\
\text { Total } \\
\text { Percent }\end{array}$} & M & 78 & 79 & 157 & $50.3 \%$ \\
\hline & F & 84 & 71 & 155 & $49.7 \%$ \\
\hline & & 162 & 150 & 312 & $100 \%$ \\
\hline & & $51.9 \%$ & $48.1 \%$ & $100 \%$ & \\
\hline
\end{tabular}

The semi-structured Interview investigated the following 3 research questions:

(1)What are you talking about when stay with your peers regarding the media use?

(2)What are you usually do when use media with your peers?

(3)How do you communicate with your peers when using media together?

Sample interview questions for K3 and P1 children:

\begin{tabular}{|l|l|}
\hline & Item \\
\hline 1 & $\begin{array}{c}\text { When there is no one at home, do you watch TV or play a tablet or play with computer } \\
\text { instead of your peer? }\end{array}$ \\
\hline 2 & When stay with friends,do you play video games or computer together? \\
\hline 3 & $\begin{array}{c}\text { Do you have anime characters or movie or TV idols you like? What 's the reason you } \\
\text { like it? Will you talk to your peers about them? }\end{array}$ \\
\hline 4 & $\begin{array}{c}\text { Do you use Internet buzzwords when communicate with your peers?Does your peers } \\
\text { know what you mean? Or do you teach them? }\end{array}$ \\
\hline
\end{tabular}

\section{Findings}

1.The role of media in peer group relations

In this section, semi-structured interviews were adopted and open-ended questions as follows:

\begin{tabular}{|l|l|}
\hline & \multicolumn{1}{|c|}{ Episode } \\
\hline 1 & $\begin{array}{l}\text { When i stay at home alone,i like watching TV,especially animation,sometimes play tablet,but } \\
\text { if my friend ask me go out or play together,i will go with them.(A 5-years-old boy in } \\
\text { Kindergarten from Xiamen) }\end{array}$ \\
\hline 2 & $\begin{array}{l}\text { A.Yes,we play games together and talk about them,we have a lot of fun.(A 6 year old boy in } \\
\text { primary school from Changsha) } \\
\text { B.No,we seldom.we watch TV or video or animation often.i like drawing on a tablet and then } \\
\text { share it with my friend.(A 5 year old girl from Beijing) }\end{array}$ \\
\hline 3 & $\begin{array}{l}\text { I love Peppa Pig best,because she doesn't need to study.they play drama,go camping,play } \\
\text { games.she is so happy.(A 4 year old girl from Shenzhen) }\end{array}$ \\
\hline 4 & $\begin{array}{l}\text { Parts of my words are learned from the Internet,For example, "xia si bao bao le } \\
\text { "youyidexiaochuan"chiguaqunzhong",amost my friends know the meaning,and sometimes } \\
\text { they taught me new words.(A 6 year old boy from Xiamen) }\end{array}$ \\
\hline
\end{tabular}

In summary,there are 3 main ways in which media are used as a part of daily life for young children in this period:

(1) Using media as a tool when together with peers. 


\section{Descriptive Statistics}

\begin{tabular}{|l|l|l|l|l|l|l|}
\hline & $\mathrm{N}$ & Range & Minimum & Maximum & Mean & Std. Deviation \\
\hline TV & 312 & 5 & -2 & 3 & 1.38 & 1.010 \\
Tablet & 312 & 5 & -2 & 3 & .43 & 2.192 \\
Computer & 312 & 5 & -2 & 3 & -.12 & 2.340 \\
Mobile phone & 312 & 5 & -2 & 3 & 1.78 & .992 \\
Video games & 312 & 5 & -2 & 3 & -1.46 & 1.536 \\
Valid N (listwise) & 312 & & & & & \\
\hline
\end{tabular}

The average value of mobile phone is 1.78 . From the average, it can be seen that children are most exposed to mobile phones, then followed by TVs, tablets, computers and video game consoles. From the standard deviation, the smallest Std. Deviation value is the mobile phone, 0.992 , which means there is little discrepancy between the way parents view the influence of the mobile phone on children. Children use various media at homes, or in the company of friends, in this process, they share different things with others, communicate different topics with others through media directly or in the later interactions, it's all a social happening.

(2) Using media as a topic in play and talk.

Table 2 The contents involved in peer group interaction

\begin{tabular}{|l|l|l|l|l|l|l|l|l|}
\hline \multicolumn{9}{|c|}{ Kercentage and mean } \\
\hline & $\begin{array}{l}\text { Alway } \\
\text { s } \\
(\%)\end{array}$ & $\begin{array}{l}\text { Often } \\
(\%)\end{array}$ & $\begin{array}{l}\text { Sometimes } \\
(\%)\end{array}$ & $\begin{array}{l}\text { Sedom } \\
(\%)\end{array}$ & $\begin{array}{l}\text { Alway } \\
\text { s(\%) }\end{array}$ & $\begin{array}{l}\text { Often } \\
(\%)\end{array}$ & $\begin{array}{l}\text { Sometimes } \\
(\%)\end{array}$ & $\begin{array}{l}\text { Sedom } \\
(\%)\end{array}$ \\
\hline Study & $\mathbf{0 ( 0 )}$ & $\mathbf{2 ( 1 3 . 3 )}$ & $\mathbf{2 ( 1 3 . 3 )}$ & $\mathbf{1 1 ( 7 3 . 3 )}$ & $\mathbf{1 ( 6 . 7 )}$ & $\mathbf{5 ( 3 3 . 3 )}$ & $\mathbf{8 ( 5 3 . 3 )}$ & $\mathbf{2 ( 1 3 . 3 )}$ \\
\hline $\begin{array}{l}\text { Animati } \\
\text { on }\end{array}$ & $\mathbf{6 ( 4 0 )}$ & $\mathbf{4 ( 2 6 . 7 )}$ & $\mathbf{5 ( 3 3 . 3 )}$ & $\mathbf{0}$ & $\begin{array}{l}\mathbf{5 ( 3 3 . 3} \\
)\end{array}$ & $\mathbf{4 ( 2 6 . 7 )}$ & $\mathbf{4 ( 2 6 . 7 )}$ & $\mathbf{2 ( 1 3 . 3 )}$ \\
\hline TV Prog & $\mathbf{4 ( 2 6 . 7 )}$ & $\mathbf{7 ( 4 6 . 7 )}$ & $\mathbf{3 ( 2 0 )}$ & $\mathbf{1 ( 6 . 7 )}$ & $\mathbf{3 ( 2 0 )}$ & $\mathbf{7 ( 4 6 . 7 )}$ & $\mathbf{4 ( 2 6 . 7 )}$ & $\mathbf{1 ( 6 . 7 )}$ \\
\hline $\begin{array}{l}\text { Video } \\
\text { Games }\end{array}$ & $\mathbf{6 ( 4 0 )}$ & $\mathbf{3 ( 2 0 )}$ & $\mathbf{4 ( 2 6 . 7 )}$ & $\mathbf{2 ( 1 3 . 3 )}$ & $\begin{array}{l}\mathbf{5 ( 3 3 . 3} \\
)\end{array}$ & $\mathbf{4 ( 2 6 . 7 )}$ & $\mathbf{3 ( 2 0 )}$ & $\mathbf{3 ( 2 0 )}$ \\
\hline Others & $\mathbf{2 ( 1 3 . 3 )}$ & $\mathbf{6 ( 4 0 )}$ & $\mathbf{6 ( 4 0 )}$ & $\mathbf{1 ( 6 . 7 )}$ & $\begin{array}{l}\mathbf{4 ( 2 6 . 7} \\
)\end{array}$ & $\mathbf{2 ( 1 3 . 3 )}$ & $\mathbf{6 ( 4 0 )}$ & $\mathbf{3 ( 2 0 )}$ \\
\hline
\end{tabular}

Vygotsky (1978) suggests that the child internalises social interactions through which they learn and develop ${ }^{7}$.By contacting with different media environment, children's learning is a tool to build up individual differences. This as certain, will have direct impact on children as they move from preschool to primary school accompanying by different culture. From the interview we can see that both for the children from kindergarten and primary school, media is a essential tool for their social interactions in peer group.

(3) Using media as means of self-development(self identity)

Friendship helps to overall situations in which children feel vulnerable. And it can also lead to new picture of themselves including stronger feeling of self as a member of certain gender, age, and ethnical origin (Danby, toward Brooked and Woodhead, 2008, p.36). ${ }^{8}$ During plays and conversations with peers children often study new values and models of behaviour. Participation in coevals' groups gives children sense of collective identity which differs one that children share with others.(Milica Jelic,2014) ${ }^{9}$ One the one side, children use the media to achieve the need for learning, thereby gaining a sense of self-realization in the peer group. On the other side, What genre of medium is chosen and what media content is preferred, which represents the individual differences of children to varying degrees.

\footnotetext{
${ }^{7}$ Vygotsky, L. S. (1978). Mind in Society: The development of Higher Mental Processes. Cambridge and London: Harvard University Press.

${ }^{8}$ Brooker, L. i Woodhead, M. (2008): Developing Positive Identities, Early Childhood in Focus 3, The Open University, Millon

Kynes, United Kingdom; NCCA (National Council for Curriculum and Assessment) Children's Early Learning and development: Research paper, Retrieved from

www.nccn.ie/en/Curriculum_and_Assessment/Early_Childrens_learning_and_dev.pdf, accessed 10.02.2014.;

${ }^{9}$ Milica Jelic,Developing a sense of identity in preschoolers,Mediterranean Journal of Social Sciences,MCSER Publishing, Rome-Italy,Vol.5 No.22 September 2014,P227
} 
Therefore, the identity of children in the peer group is also established through differences, thus different peer relationships are also built up. In a word, the use of media is a essential complementary way to enhance peer relations. media use is just a part of daily life in the interaction with friends.

2.What kind of similarities and differences can be found in gender and grade when they use the media? In this section, AVONA test and T test were performed to describe the differences of gender and grade in media use.

\section{Table 3 Children of different gender in TV program viewing}

\begin{tabular}{|c|c|c|c|}
\hline \multirow[b]{3}{*}{ News Program } & \multirow[b]{3}{*}{ Equal variances assumed } & \multicolumn{2}{|c|}{ Levene's Test for Equality of Variances } \\
\hline & & $\mathbf{F}$ & Sig. \\
\hline & & 2.925 & .88 \\
\hline TV series & Equal variances assumed & 37.483 & .000 \\
\hline Movies & Equal variances assumed & 8.949 & .003 \\
\hline Variety show & Equal variances assumed & 26.288 & .000 \\
\hline Music show & Equal variances assumed & 2.912 & .089 \\
\hline Sports Program & Equal variances assumed & 10.985 & .001 \\
\hline Country show & Equal variances assumed & 4.000 & .046 \\
\hline Military Program & Equal variances assumed & 42.469 & .000 \\
\hline Economic Program & Equal variances assumed & 4.000 & .046 \\
\hline children's Program & Equal variances assumed & 0.375 & .541 \\
\hline $\begin{array}{l}\text { Science and } \\
\text { Program }\end{array}$ & educationEqual variances assumed & 7.489 & .007 \\
\hline Fashion show & Equal variances assumed & 0.001 & .971 \\
\hline
\end{tabular}

According to the test, in the gender differences in TV content(Table 5): significant differences have been shown in TV dramas, movies, variety shows, sports programs, military programs, science and education programs in gender. Boys has a higher average score on movies(0.29vs0.22), sports(0.08vs0.04), military programs(0.06vs0.00), and science and education programs $(0.36 \mathrm{vs} 0.28)$. while girls are higher on average for TV shows $(0.26 \mathrm{vs} 0.13)$ and variety shows $(0.44 \mathrm{vs} 0.29)$ than boys.

Table4 Children's choices of TV programs in different grades

\begin{tabular}{|c|c|c|c|c|c|}
\hline & Gender & $\mathrm{N}$ & Mean & Std. Deviation & Std. Error Mean \\
\hline \multirow[t]{2}{*}{ News Program } & 1 & 157 & .07 & .256 & .020 \\
\hline & 2 & 155 & .10 & .297 & .024 \\
\hline \multirow[t]{2}{*}{ TV series } & 1 & 157 & .13 & .334 & .027 \\
\hline & 2 & 155 & .26 & .439 & .035 \\
\hline \multirow[t]{2}{*}{ Movies } & 1 & 157 & .29 & .457 & .036 \\
\hline & 2 & 155 & .22 & .415 & .033 \\
\hline \multirow[t]{2}{*}{ Variety show } & 1 & 157 & .29 & .454 & .036 \\
\hline & 2 & 155 & .44 & .498 & .040 \\
\hline \multirow[t]{2}{*}{ Music show } & 1 & 157 & .13 & .334 & .027 \\
\hline & 2 & 155 & .16 & .369 & .030 \\
\hline \multirow[t]{2}{*}{ Sports Program } & 1 & 157 & .08 & .276 & .022 \\
\hline & 2 & 155 & .04 & .194 & .016 \\
\hline \multirow[t]{2}{*}{ Country show } & 1 & 157 & .01 & .080 & .006 \\
\hline & 2 & 155 & .00 & .000 & .000 \\
\hline \multirow[t]{2}{*}{ Military Program } & $\overline{1}$ & 157 & .06 & .233 & .019 \\
\hline & 2 & 155 & .00 & .000 & .000 \\
\hline \multirow[t]{2}{*}{ Economic Program } & 1 & 157 & .01 & .080 & .006 \\
\hline & 2 & 155 & .00 & .000 & .000 \\
\hline \multirow[t]{2}{*}{ children's Program } & 1 & 157 & .96 & .192 & .015 \\
\hline & 2 & 155 & .95 & .208 & .017 \\
\hline \multirow[t]{2}{*}{ Science and education Program } & 1 & 157 & .36 & .481 & .038 \\
\hline & 2 & 155 & .28 & .452 & .036 \\
\hline \multirow[t]{2}{*}{ Fashion show } & 1 & 157 & .03 & .158 & .013 \\
\hline & 2 & 155 & .03 & .159 & .013 \\
\hline
\end{tabular}


In the choice of TV contents, the Levene method's F-value test results reach a significant level of $\mathrm{P}<0.05$, it shows there is a significant difference between kindergarten and primary school. From the results(Table 6) we can see that children in the kindergarten prefer music programs $(\mathrm{K} 0.26, \mathrm{P} 0.12)$, while entering primary school, they tend to choose TV shows $(\mathrm{K} 3=0.13, \mathrm{P} 1=0.21)$, sports programs $(\mathrm{K} 3=0.02, \mathrm{P} 1=0.07)$ and children's programs $(\mathrm{K} 3=0.92 . \mathrm{P} 1=0.97)$.

\section{Table 5}

\section{Group Statistics}

\begin{tabular}{|c|c|c|c|c|c|}
\hline & Grade & $\mathbf{N}$ & Mean & Std. Deviation & Std. Error Mean \\
\hline \multirow[t]{2}{*}{ News Program } & Kindergarten & 62 & .10 & .298 & .038 \\
\hline & Primary School & 250 & .08 & .272 & .017 \\
\hline \multirow[t]{2}{*}{ TV series } & Kindergarten & 62 & .13 & .338 & .043 \\
\hline & Primary School & 250 & .21 & .407 & .026 \\
\hline \multirow[t]{2}{*}{ Movies } & Kindergarten & 62 & .24 & .432 & .055 \\
\hline & Primary School & 250 & .26 & .440 & .028 \\
\hline \multirow[t]{2}{*}{ Variety show } & Kindergarten & 62 & .31 & .465 & .059 \\
\hline & Primary School & 250 & .38 & .485 & .031 \\
\hline \multirow[t]{2}{*}{ Music show } & Kindergarten & 62 & .26 & .441 & .056 \\
\hline & Primary School & 250 & .12 & .321 & .020 \\
\hline \multirow[t]{2}{*}{ Sports Program } & Kindergarten & 62 & .02 & .127 & .016 \\
\hline & Primary School & 250 & .07 & .259 & .016 \\
\hline \multirow[t]{2}{*}{ Country show } & Kindergarten & 62 & .00 & .000 & .000 \\
\hline & Primary School & 250 & .00 & .063 & .004 \\
\hline \multirow[t]{2}{*}{ Military Program } & Kindergarten & 62 & .03 & .178 & .023 \\
\hline & Primary School & 250 & .03 & .165 & .010 \\
\hline \multirow[t]{2}{*}{ Economic Program } & Kindergarten & 62 & .00 & .000 & .000 \\
\hline & Primary School & 250 & .00 & .063 & .004 \\
\hline \multirow[t]{2}{*}{ children's Program } & Kindergarten & 62 & .92 & 275 & .035 \\
\hline & Primary School & 250 & .97 & .176 & .011 \\
\hline \multirow[t]{2}{*}{ Science and education Program } & Kindergarten & 62 & .34 & .477 & .061 \\
\hline & Primary School & 250 & .32 & .466 & .029 \\
\hline \multirow[t]{2}{*}{ Fashion show } & Kindergarten & 62 & .03 & .178 & .023 \\
\hline & Primary School & 250 & .02 & .153 & .010 \\
\hline
\end{tabular}

On the use of mobile phones for surfing the internet, the average value of kindergartens is 0.45 , while the first grade of primary school is only 0.02 . At the same time, playing games on mobile phones, kindergarten children is 0.84 , while primary school students is only 0.33 . The different in media needs resulting in choosing different media content. On using mobile phones as learning tools, the standard deviation of the primary school students group is shown as the lowest, the value is 1.391,which indicates that the participants has the least difference in the using of this item. Mobile phone as one of the children's learning tools, especially when they entering primary school, has become an inevitable trend.(Table 6 shown below) 


\section{Report}

\begin{tabular}{|c|c|c|c|c|c|}
\hline \multicolumn{2}{|l|}{ Grade } & $\begin{array}{l}\text { Make calls and } \\
\text { text message }\end{array}$ & Surf the internet & Play games & learning tools \\
\hline \multicolumn{2}{|c|}{ Kindergarte Mean } & .29 & 45 & 84 & .76 \\
\hline n & $\begin{array}{l}\text { Std. } \\
\text { Deviation }\end{array}$ & 2.557 & 2.101 & 1.909 & 2.078 \\
\hline \multirow{2}{*}{$\begin{array}{l}\text { Primary } \\
\text { school }\end{array}$} & Mean & .29 & .02 & .33 & .91 \\
\hline & $\begin{array}{l}\text { Std. } \\
\text { Deviation }\end{array}$ & 2.198 & 2.452 & 2.354 & 1.391 \\
\hline
\end{tabular}

\section{What's the influence of media use(length of time) on peer relations in the transition to primary school?}

In this section, exploratory factor analysis $(\mathrm{KMO}=.917, \sin =0.000)$ and correlation analysis were performed on the children's media use and peer relations.(Table 7)

Factor Analysis

\begin{tabular}{|c|c|c|c|}
\hline & \multicolumn{3}{|c|}{ Component } \\
\hline & 1 & 2 & 3 \\
\hline Is cooperative & .629 & & \\
\hline Makes friends easily & .503 & & \\
\hline Shows self-control & .718 & & \\
\hline Stands up for other children's rights("That's his!") & .638 & & \\
\hline Follows rules & 801 & & \\
\hline Apologizes for accidental behavior that may upset others & .656 & & \\
\hline Gives in or compromises with peers when appropriate & .700 & & \\
\hline Responds appropriately when corrected & 628 & & \\
\hline Comforts other children who are upset & & .572 & \\
\hline Invites other children to play & & .752 & \\
\hline Smiles and laughs with other children & & .640 & \\
\hline Plays with several different children & & .629 & \\
\hline Tries to understand another child's behavior("Why are you crying?") & & .603 & \\
\hline Is accepted and liked by other children & & .673 & \\
\hline Shares toys and other belongings & & .605 & \\
\hline Takes turns with toys and other objects & & .595 & \\
\hline Shows affection for other children & & .709 & \\
\hline Is confident in social situations & & & .793 \\
\hline Participates in family or clasroom discusions & & & .599 \\
\hline Has skills or abilities that are admired by peers & & & .689 \\
\hline$\%$ of variance & $38.31 \%$ & $44.7 \%$ & $50.1 \%$ \\
\hline
\end{tabular}

Extraction Method: Principal Component Analysis. 
Table 8 Coefficient Correlations

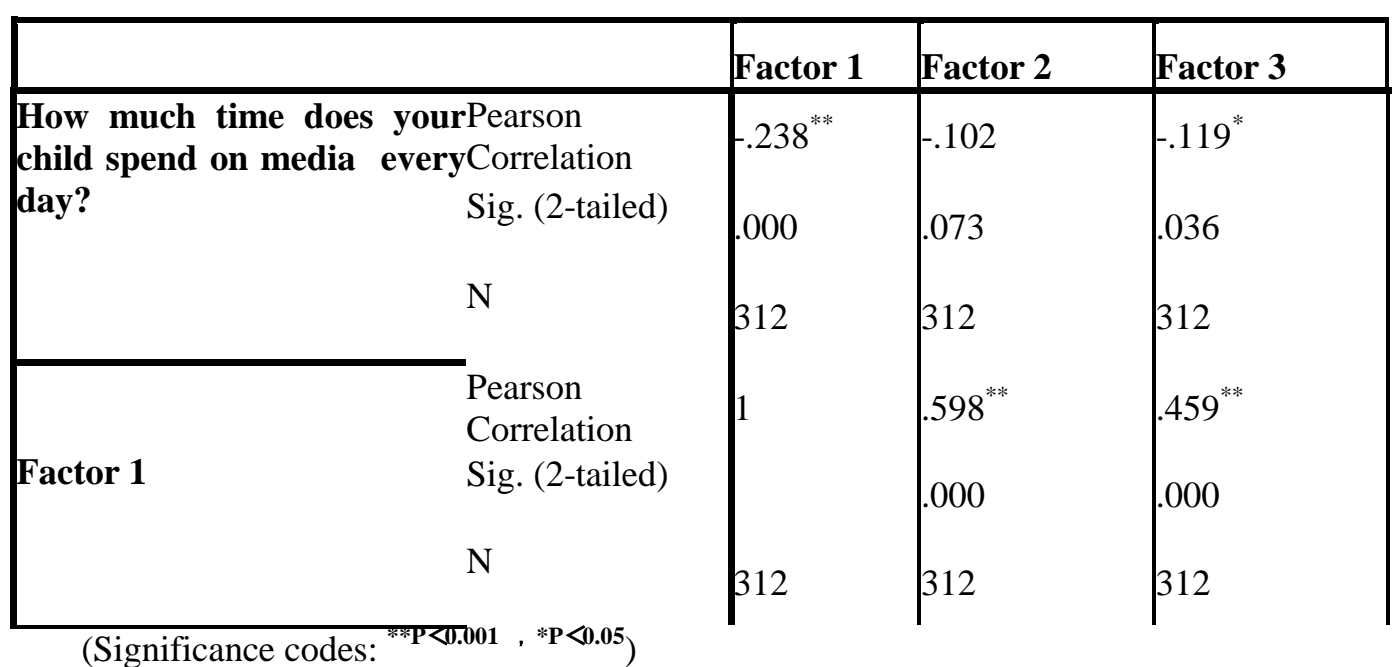

An exploratory factor analysis was performed and 3 factors were extracted in the social behavior scale:,(1) social understanding (2)peer acceptance and reject;(3).social participation. The lenth of time in children's media use is significantly negative related to social understanding and participation, but it is not significant with peer acceptance. $(\mathrm{P}=.073>0.05)$

Table 8 Children's media use in the three levels of variable analysis

\begin{tabular}{|c|c|c|c|c|c|}
\hline Effect & Value & $\mathrm{F}$ & $\begin{array}{l}\text { Hypothesis } \\
\text { df }\end{array}$ & Sig. & $\begin{array}{l}\text { Partial Eta } \\
\text { Squared }\end{array}$ \\
\hline \multirow{2}{*}{$\begin{array}{l}\text { How much time doesPillai's Trace } \\
\text { your child spend on Wilks' Lambda } \\
\text { media every day }\end{array}$} & .112 & 2.366 & 15.000 & .002 & .037 \\
\hline & .891 & 2.380 & 15.000 & .002 & .038 \\
\hline $\begin{array}{ll}\text { Hodia every day } & \text { Hotling's } \\
& \text { Trace }\end{array}$ & .118 & 2.389 & 15.000 & .002 & .038 \\
\hline $\begin{array}{l}\text { Roy's Larges } \\
\text { Root }\end{array}$ & .077 & $4.731^{\mathrm{c}}$ & 5.000 & .000 & .072 \\
\hline
\end{tabular}

Roy's Largest $\operatorname{Root}(\mathrm{p}=.000<0.05)$ shows that there is a singnificant difference in the mean among the 3 variables. Children take the informal way to interact preferentially with others to form relationships with peers in the transition period.(Dale F.Hay,Payne,Chadwick,2004)Influences of the environment on children's physical and emotional development have been stated theoretically and empirically(Lewin,1931,Vygotsky,1967,Wachs,1985,Hart,1993)Lewin proposed the eqution $B=f(P, E)$ which states that behavior $(B)$ is a function ( $f$ ) of the person $(P)$ in their environment (E).(Lewin,1931) Regarding of the 3 predictable variables among children's peer relationship, The author makes the following hypothesis about the relationship between these variables.(Table 9)

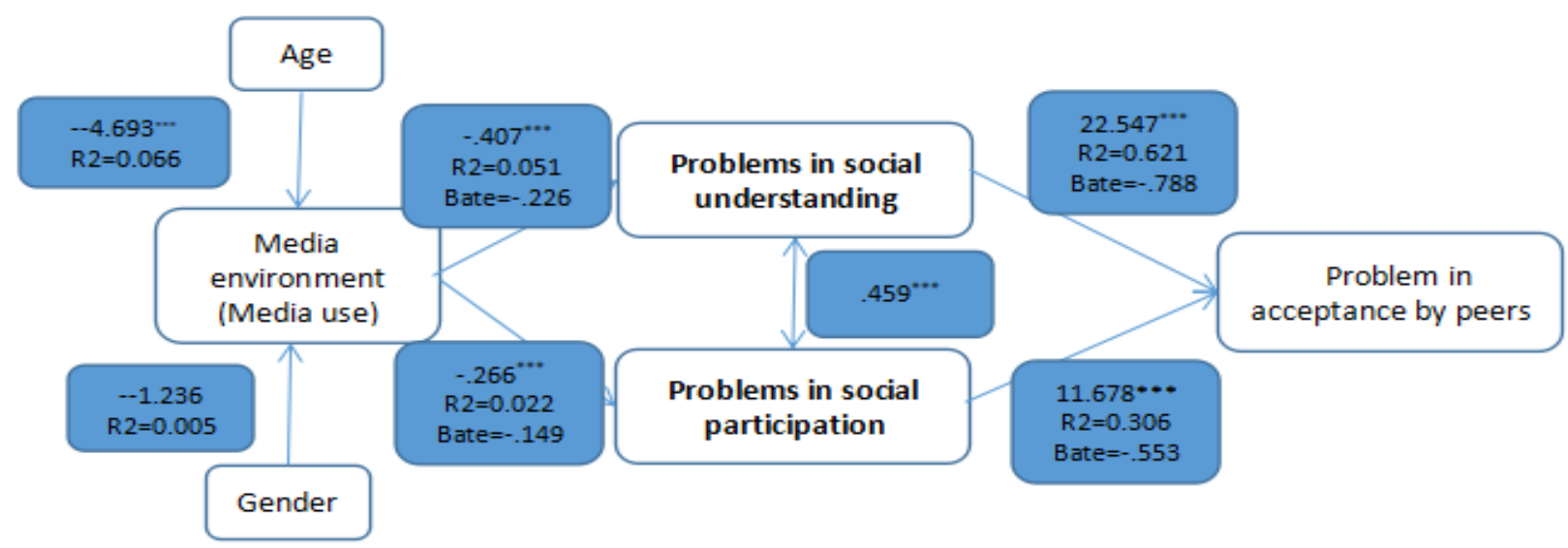

Correlation,T test and LISREL was used to test this hypothesis. 
In children's peer relationship, age was significantly different in the length of time in media use ( $\mathrm{t}=-$ $4.693, \mathrm{P}=0.000<0.001)$, but did not show significant differences in gender $(\mathrm{t}=-1.236, \mathrm{P}=.217>0.05)$ differences.

According to Table 9, The length of time in children's media use is significantly related to social understanding and social participation, Its Bate coefficient affecting two variables is $0.226(\mathrm{t}=-.407, \mathrm{P}=0.000), .149(\mathrm{t}=-$ $.266, \mathrm{P}=0.000$ ), which both show a significant difference, and it has a greater impact on social understanding. In that way, it means the longer time a child spends in the media use, the worse his/her social understanding will be.

According to the regression coefficient values, it can be known that the social acceptance and social participation in the children's peer acceptance effect values are 0.621 and 0.306 respectively, and the significance test of the path coefficients reached a significant level of 0.001. $(\mathrm{P}=0.000)$

\section{Conclusions and Recommendations}

The findings are generally in keeping with the existing literature. Children's media use is an important supplement in the process of social development in the transition period, but it does not replace the communication and interaction between children and real people. The preference of children in media use is the social processing in which they build peer relationship.

Children use media as a tool or topic to communicate with peers or to company friends, or even to seek new connections with new peers.In children's middle childhood period, different media use among children can contribute to the forming of the self identity and promote the formation of peer groups.

From the content of media use in children in this transition phase, gender and age differences can be seen. Girls prefer TV shows and variety shows to sports program, military program, science and education program which are more popular with boys. Meanwhile, children in the kindergarten prefer music programs(K0.26,P0.12), while entering primary school, they tend to choose $\mathrm{TV}$ shows $(\mathrm{K} 3=0.13, \mathrm{P} 1=0.21)$, sports programs $(\mathrm{K} 3=0.02, \mathrm{P} 1=0.07)$ and children's programs. Further study needs to explore what kind of media content children like. Therefore, it is important to adopt different education methods at this transition stage. Psychological adjustments from preschool to primary school is important for both children and parents, as well as for school. Parents and teachers should emphasis more importance on the interactions with children and respond to their work and needs and support (Greenspan,1989,1992a; Smolkin,1999)

Because children show significant gender differences and age differences in the contents of media use, it may be a favorable way to evaluate current practice at schools and curriculum. For example, from the perspective of the school, we should pay attention to the artistry of the curriculum when they entry to primary school. As for family, we can continue to use the media to cultivate children's aesthetic emotions. And also, because there is a significant gender difference in the choice of media content, it is not a wise way to prohibit contact with any media after children enter primary school. Instead, parents should stimulate their various potentials according to their own preferences.

The length of time in media use has different effects on peer relationships. In peer relationships, the longer the child's media is used, the worse the social understanding and social participation will be, which eventually affect peer acceptance.

\section{Reference}

Alexander, K. L., \& Entwisle, D. R. (1988). Achievement in the first 2 years of school: Patterns and processes. Monographs of the Society for Child Development, 53(2, Serial No. 218).

Berk, L.E. (2008). Psihologija cjeloživotnog razvoja. Jastrebarsko: Naklada Slap.

Blaževic, Ines,Family, Peer and School Influence on Children's Social Development,World Journal of Education, v6 n2 p42-49 2016

Bronfenbrenner, U. (1979). The Ecology of Human Development: Experiments by Nature and Design. Cambridge, MA: Harvard University Press.

Bronfenbrenner, U. (1992). Ecology of the Family as a Context for Human Development: Research Perspectives. Developmental Psychology, 22, 6, 723-742.

Bronfenbrenner, U., and Morris, P. (2006). The Bioecological Model of Human Development. In Lerner, R.M. (Ed.) Theoretical Models of Human Development (Volume 1 of Handbook of Child Psychology) (6th Edition). pp 793-828. Hoboken, NJ: Wiley.

Brooker, L. i Woodhead, M. (2008): Developing Positive Identities, Early Childhood in Focus 3, The Open University, Millon 
Coie, J. D., Dodge, K. A., \& Coppotelli, H.(1982).Dimensions and Types of Social Status: A Cross-Age Perspective.Developmental Psychology, 4, 557-570.

Dale F.Hay,Alexandra Payne and Andrea Chadwick,Peer relations in childhood,Journal of Child Psychology and Psychiatry 45:1 (2004), p84-108

Dockett, S., \& Perry, B. (2007). Children's transition to school: Changing expectations. In A-W. Dunlop, \& H. Fabian (Eds.), Informing transitions in the early years: research policy and practice (1 ed., pp. 92-104). [7] London: Open University Press.

Fabian, H. (2007). Informing transitions. In A-W. Dunlop \& H. Fabian (Eds.) Informing Transitions in The Early Years (pp. 3-17). London: McGraw-Hill Open University Press.

Feinberg, M.E., Jones, D.E., Roettger, M.E., Solmeyer, A. and Hostetler, M."Long-term follow-up of a randomized trial of family foundations: Effects on children"s emotional, behavioral, and school adjustment," Journal of Family Psychology, 28(6), p.821, 2014.

Greenspan, S. I. (1989). Development of the ego: Implications for personality theory, psychopathology, and the psychotherapeutic process. Madison, CT: International Universities Press.

Greenspan, S. I. (1992a). Infancy and early childhood: The practice of clinical assessment and intervention with emotional and developmental challenges. Madison, CT: International Universities Press.

Ines Blažević,Family, Peer and School Influence on Children's Social Development, World Journal of Education,Vol. 6, No. 2; 2016,p42-49.

Klarin, M. (2002). Socijalna kompetencija u kontekstu emocionalnih i bihevioralnih korelata, Mediji, kultura i odnosi s javnošću, 1 (1), 78-80

Kuperschmidt, J. B., \& Coie, J. D. (1990). Preadolescent peer status, aggression, and school adjustment as predictors of externalizing problems in adolescence. Child Development, 61, 1350-1362.

Kynes, United Kingdom; NCCA (National Council for Curriculum and Assessment) Children's Early Learning and development: Research paper, Retrieved from www.nccn.ie/en/Curriculum_and_Assessment/Early_Childrens_learning_and_dev.pdf, accessed 10.02.2014.;

Ladd GW, Buhs ES, Seid M. Children's initial sentiments about kindergarten: Is school liking an antecedent of early classroom participation and achievement? Merrill-Palmer Quarterly. 2000;46:255-279

Ladd, G. W., \& Dinella, L. M. (2009). Continuity and change in early school engagement: Predictive of children's achievement trajectories from first to eighth grade? Journal of Educational Psychology, 101(1), 190-206.

Love, J. M., Logue, M. E., Trudeau, J. V., \& Thayer, K. (1992). Transitions to Kindergarten in American schools (Contract No. LC 88089001). Portsmouth, NH: U.S. Department of Education.

Mashburn, A., and Pianta, R. (2006). Social Relationships and School Readiness. Early Education and Development, 17, 151-176.

Milica Jelic,Developing a sense of identity in preschoolers,Mediterranean Journal of Social Sciences,MCSER Publishing, Rome-Italy,Vol.5 No.22,September 2014,P227

Peters, S. (2010). Literature Review: Transition from Early Childhood Education to School - Report to the Ministry of Education New Zealand. Retrieved November 2013, from http://lnxweb1.manukau.ac.nz/_data/assets/pdf_file/0008/85841/956_ECELitReview.pdf

Pianta, R. C., Cox, M. J., Taylor, L., \& Early, D. (1999). Kindergarten teachers' practices related to the transition to school: Results of a national survey. Elementary School Journal, 100(1), 71-86.

Rimm-Kaufman, S. E.,\&Pianta, R. C. (2000). An ecological perspective on the transition to kindergarten: A theoretical framework to guide empirical research. Journal of Applied Developmental Psychology, 21, 491-511.

Rimm-Kaufman, S. E.,\&Pianta, R. C. (2005). Family-school communication in preschool and kindergarten in the context of a relationship-enhancing intervention. Early Education and Development,16, 287-316.

Rimm-Kaufman, S. E.,\&Pianta, R. C. (2005). Family-school communication in preschool and kindergarten in the context of a relationship-enhancing intervention. Early Education and Development, 16, 287-316.

Rous, B., Hallam, R., Harbin, G., McCormick, K, \& Jung, L. (2007). The transition process for young children with disabilities: A conceptual framework. Infants and Young Children, 20(2), 135-148.

Rubin KH, Bukowski W, Parker J. Peer interactions, relationships, and groups. In: Eisenberg N, Damon W, Lerner RM, eds.New York: Wiley; 2006:571-645.Handbook of child psychology: Volume 3, Social, emotional, and personality development (6th ed).

Rubin, K. H., Dwyer, K. M., Booth, C. L., Kim, A. H., Burgess, K. B., \& Rose-Krasnor, L.(2004). Attachment, friendship, and psychosocial functioning in early adolescence.Journal of Early Adolescence, 24, 326-356.

Sayers, Mary; West, Sue; Lorains, Jen; Laidlaw, Bella; Moore, Tim G and Robinson, Rachel. Starting school: A pivotal life transition for children and their families [online]. Family Matters, No. 90, 2012: 45-56.

Schaffer, H. R. (2000). Social development. Oxford: Blackwell Publishers Inc. 
Shepard, L. A. and Smith, M. L. 1989. Escalating kindergarten curriculum, Urbana, IL: ERIC Clearinghouse on Elementary and Early Childhood Education. (ERIC Document Reproduction Service No. ED 308 989)

Suess, D., Suoninen, A., Garitaonandia, C., Juaristi, P., Koikkalainen, R., \& Oleaga, J. A. (1998). Media Use and the Relationships of Children and Teenagers with their Peer Groups: A Study of Finnish, Spanish and Swiss Cases. European Journal of Communication, 13(4), 521-538.

Smolkin, L. B. (1999). The practice of effective transitions. Players who make a winning team. In R. C. Pianta \& M. J. Cox (Eds.), The transition to kindergarten (pp. 325- 349). Baltimore, MD, USA: Paul H. Brookes Publishing Co.

Unicef:《 the state of the world's children 2017:children in a gigital word》 Media Literacy and the Digital Age, Sean Edward Watkins, A Thesis Submitted to the Graduate College of Bowling Green State University, 2009, p.16.

Vygotsky, L. S. (1978). Mind in Society: The development of Higher Mental Processes. Cambridge and London: Harvard University Press. 